\title{
Analisis Hubungan Kualitas Kehidupan Kerja Perawat dengan Kualitas Hidup Dimasa Pandemi Covid-19 di Rumah Sakit Umum Daerah M. Natsir
}

\author{
Febrian Rahmat Suwandi ${ }^{1 *}$, Rahmi Fahmy ${ }^{2}$, Dewi Murni ${ }^{3}$, Nelwati ${ }^{4}$, \\ Mira Susanti ${ }^{5}$, Zifriyanti Minanda Putri ${ }^{6}$ \\ ${ }^{1}$ Pascasarjana Fakultas Keperawatan Universitas Andalas Padang \\ ${ }^{2}$ Fakultas Ekonomi Universitas Andalas Padang \\ ${ }^{3,4,6}$ Fakultas Keperawatan Universitas Andalas Padang \\ ${ }^{4}$ Rumah Sakit Umum Pusat M. Djamil Padang \\ *Correspondence email: febrianrahmat130295@gmail.com
}

\begin{abstract}
Abstrak. Rumah sakit mengalami peningkatan pelayanan di masa pandemi COVID-19. Hal ini membuat perubahan kondisi yang dialami oleh tenaga kesehatan terutama perawat. Dampak yang terjadi pada perawat mulai dari kondisi fisik yang mudah lelah setelah bekerja, stress akan tingginya risiko penularan penyakit, lingkungan kerja yang kurang baik dengan sarana dan prasarana yang kurang dan sulitnya untuk bersosialisasi dengan tenaga kesehatan lain. Keadaan seperti ini memengaruhi kualitas kehidupan kerja perawat mulai dari dimensi Work Life/Home Life, Work Design, Work Context, Work World. Tujuan penelitian ini adalah menganalisis hubungan kualitas kehidupan kerja perawat dengan kualitas hidup perawat di masa pandemi COVID-19 di RSUD M. Natsir. Design penelitian Deskriptif kuantitatif dengan metode cross sectional survey online. Populasi Seluruh perawat pelaksana yang terlibat langsung dalam pelayanan pasien COVID-19 dengan jumlah sampel 65 orang. Instrumen penelitian ini menggunakan kuesioner Quality of Nursing Work Life dan WHOQOL-BREFF. Pengumpulan data dengan analisis distribusi frekuensi dan Analisis SEM PLS 3.0. Hasil penelitian didapatkan 3 dimensi kualitas kehidupan kerja perawat yang berhubungan signifikan dengan kualitas hidup yaitu dimensi Work Design, Work Context dan Work World dengan nilai masing-masing dimensi 0,000, 0,025 dan 0,019 artinya (nilai sig) $<0,05$ sedangkan dimensi Work Life /Home Life (nilai sign) sebesar 0,497 >0,05 dengan nilai $\mathrm{T}$ statistik sebesar $0,007<\mathrm{T}$ tabel 1,645 maka dimensi ini tidak berhubungan signifikan terhadap kualitas hidup perawat. Berdasarkan hasil penelitian ini diharapkan bagi manajemen dan rumah sakit lebih memperhatikan terkait dengan kepuasan kerja, beban kerja, komunikasi dalam lingkungan kerja, citra kerja, gaji dan keamanan dalam melakukan pelayanan di masa pandemi COVID-19.
\end{abstract}

Kata Kunci: Kualitas Kehidupan Kerja Perawat, Kualitas Hidup, Pandemi Covid-19

Abstract. During the pandemic Covid-19, hospital must give the care more. It makes the medical staff condition changes, especially nurse. It makes the nurse got fatigue more, stressing of high-risk disease transmission, unwell work environment, lack of facilities and infrastructure and lack of communication among the medical staff. These condition influences the nursing work life quality such as: Work Life / Home Life, Work Design, Work Context, Work World. The aim of this research is to analyze the relationship between nursing work life quality and nursing life quality during Covid-19 pandemic at RSUD M. Natsir. The research design is quantitative descriptive by using cross sectional survey online. The population is all executive nurses who involve directly in Covid-19 patient care, namely 65 persons. The research instrument used questionnaire of quality of Nursing Work Life dan WHOQOL-BREFF. The data collection used frequency distributed analysis and SEM PLS 3.O. It's gotten three dimension of nursing work life quality which is related with life quality significantly namely Work Design, Work Context and Work World with the value for each dimension 0,000, 0,025 and 0,019 means (significant value) <0,05 while Work Life /Home Life dimension (significant value) s 0,497 > 0,05 with $T$ statistic value 0,007 < T table 1,645 so this dimension does not have significant correlation with nursing work life. It is hoped the hospital management give more attention for work satisfaction, work burden, work communication, work image, salary, and safety during the duty in caring the patient of Covid-19.

Keyword: nursing work life quality, nursing life quality, covid 19

\section{PENDAHULUAN}

Kualitas hidup di masa pandemi COVID-19 haruslah dijaga dan merupakan hal yang utama bagi kepentingan masyarakat. World Health Organization (WHO) mengimbau bahwa masyarakat harus menjaga kualitas hidup mereka seperti: menjaga kesehatan, hubungan sosial, ekonomi dan religious. Menurut World Health Organization (WHO), (2018) Kualitas hidup adalah suatu keadaan di mana individu tidak hanya terbebas dari penyakit dan kelemahan, namun juga terjadi keseimbangan antara fungsi fisik, mental, dan sosial. Sehingga pengukuran kualitas hidup dapat dilihat dari empat bidang fungsi yaitu fisik, psikologis, sosial dan lingkungan..

Pandemi COVID-19 di Indonesia memengaruhi dan membatasi aktivitas sehari-hari kemudian berdampak pada kualitas hidup seseorang, seperti kesehatan fisik, kesehatan psikologis, hubungan sosial dan lingkungan. Di sisi lain aspek negatif dari individu setelah melakukan pekerjaan bisa berupa beban kerja yang tinggi, lingkungan yang kurang mendukung yang di tandai dengan individu merasakan lelah, frustrasi, 
kemarahan, depresi, sedangkan konsekuensi negatif yang diperoleh berupa kesulitan tidur, menghindari pekerjaan tersebut, memiliki rasa takut dan trauma akan pekerjaan (Remegio et al., 2021).

Perawat sebagai tenaga kesehatan di masa pandemi COVID-19 ini akan rentan terpapar virus, karena perawat terlibat langsung dalam memberikan pelayanan asuhan keperawatan dan perawat memiliki kontak erat dengan pasien. Berdasarkan penelitian yang dilakukan Sugianto et al., (2021) kondisi fisik yang lemah, mudah lelah, stress kerja dan beban kerja yang tinggi pada perawat akan menjadi rentan terpapar virus serta masalah kesehatan lainnya karena fisik mengalami penurunan kondisi yang tidak baik.

Perawat sebagai salah satu tenaga kesehatan yang kualitas hidupnya dipengaruhi oleh kualitas kehidupan kerja di mana adanya perubahan yang dialami terhadap beban kerja, kondisi kerja dan isu-isu lain terkait dengan keperawatan, hal ini merupakan upaya yang penting dalam menangani masalah terhadap kualitas kehidupan kerja perawat Oyoh et al., (2017). Berdasarkan hasil survey dalam (Astriani et al., 2021) mengatakan bahwa pekerjaan dapat menghabiskan setengah hidup seseorang dan hasil riset menemukan bahwa $68,4 \%$ pegawai tidak puas akan pekerjaannya.

Menurut Viselita et al., (2019) kualitas kehidupan kerja merupakan persepsi seseorang atau karyawan terhadap pekerjaan, organisasi, manajernya sedangkan kualitas kehidupan kerja perawat adalah sejauh mana seorang perawat dapat memenuhi kebutuhan pribadinya melalui pengalaman yang telah mereka jalani dalam organisasi sambil mencapai tujuan organisasinya.

Berdasarkan studi pendahuluan yang dilakukan melalui wawancara via chat WhatsApp terhadap 5 orang perawat yang terlibat langsung dalam penanganan pasien COVID-19 di RSUD M. Natsir, perawat mengatakan sebelum mereka ditunjuk untuk menjadi seorang perawat yang berada dan terlibat langsung dalam penanganan pasien COVID-19 ada perasaan yang kurang baik, cemas dan takut akan penularan penyakit, namun adanya sosialisasi dari pihak manajemen terkait dengan penanganan dan perawatan yang akan dilakukan terhadap pasien COVID-19.

Pada wawancara ini rata-rata perawat mengatakan penurunan akan kondisi fisik dikarenakan keadaan yang mendesak akan situasi yang sibuk, mereka pengatakan mudah lelah akibat beban kerja yang tinggi dan lelah dalam penggunaan alat pelindung diri (APD). Dampak psikologis yang dialami perawat, mereka mengatakan adanya kecemasan dalam bekerja karena memiliki risiko akan penularan penyakit dan semakin meningkat akan angka kejadian COVID-19 pada tenaga kesehatan. Dampak sosial mereka mengatakan kurangnya bersosialisasi dengan orang lain dan tim tenaga kesehatan lain yang mengakibatkan pekerjaan sedikit terhambat dan lingkungan yang mendukung terhadap sarana dan prasaranan dalam bekerja.

Terkait dengan kualitas kehidupan kerja mereka mengatakan dalam keadaan Pandemi COVID-19 susah bagi mereka untuk ini menyeimbangkan pekerjaan di rumah sakit dengan pekerjaan rumah, karena ada beberapa hal yang mesti di jaga dengan baik seperti kebersihan, terkadang timbul rasa khawatir setelah melakukan pekerjaan dari rumah sakit ketika pulang. Begitu pun keadaan ketika bekerja di Rumah Sakit protokol kesehatan haruslah dijaga dengan baik.

\section{METODE}

Jenis Penelitian ini merupakan penelitian kuantitatif dengan menggunakan metode penelitian Deskriptif Kuantitatif dengan metode cross sectional survey online. Populasi dalam penelitian ini adalah seluruh perawat yang terlibat langsung dalam penanganan pasien COVID-19 di RSUD M.Natsir yang berjumlah 65 orang terbagi atas 3 Ruangan yaitu Intalasi Gawat Darurat (IGD), Ruangan Anak dan Ruangan Isolasi Serunai. Teknik pengambilan Sampel pada penelitian ini adalah Total Sampling. Penelitian ini telah mendapatkan Ethical Approval dengan No: 280/KEPK/2021. Instrumen penelitian ini menggunakan kuesioner Quality of Nursing Work Life dan WHOQOLBREFF. Pengumpulan data dengan analisis distribusi frekuensi dan Analisis SEM PLS 3.0.

\section{HASIL DAN PEMBAHASAN \\ Analisa Univariat \\ Karakteristik Responden}

Berdasarkan hasil penelitian didapatkan bahwa dari 65 jumlah total responden sebagian besar responden berusia 26-35 Tahun atau pada masa dewasa awal sebanyak 53 orang $(81.5 \%)$, sebagian besar responden berjenis kelamin perempuan sebanyak 53 orang $(81.5 \%)$, diantaranya berpendidikan terakhir D3 Keperawatan sebanyak 35 orang (53.8\%), sebagian besar Status Pernikahan Menikah sebanyak 52 orang (80.0\%) diantaranya 45 orang $(69.2 \%)$ diantaranya sudah memiliki anak, diantaranya berstatus kepegawaian PNS sebanyak 40 orang $(61.5 \%)$ dan diantaranya dinas di Ruangan Isolasi Serunai sebanyak 27 orang (41.5\%). Detail lebih lanjut bisa dilihat pada tabel 1 dibawah ini: 
Febrian Rahmat Suwandi, Rahmi Fahmy, Dewi Murni, Nelwati, Mira Susanti dan Zifriyanti Minanda Putri, Analisis Hubungan Kualitas Kehidupan Kerja Perawat dengan Kualitas Hidup Dimasa Pandemi Covid-19 di Rumah Sakit Umum Daerah M. Natsir

Tabel 1. Karakteristik Responden

\begin{tabular}{|c|c|c|c|}
\hline No & Karakteristik & Frekuensi (f) & Persentase (\%) \\
\hline \multirow[t]{6}{*}{1} & Usia & & \\
\hline & a. 17-25 Tahun & 0 & 0 \\
\hline & b. 26-35 Tahun & 53 & 81.5 \\
\hline & c. $36-45$ Tahun & 9 & 13.8 \\
\hline & d. $46-55$ Tahun & 3 & 4.6 \\
\hline & e. 56-65 Tahun & 0 & 0 \\
\hline \multirow[t]{3}{*}{2} & Jenis Kelamin & & \\
\hline & a. Laki-Laki & 12 & 18.5 \\
\hline & b. Perempuan & 53 & 81.5 \\
\hline \multirow[t]{4}{*}{3} & Pendidikan & & \\
\hline & a. D3 Keperawatan & 35 & 53.8 \\
\hline & b. Ners & 30 & 46.2 \\
\hline & c. $\$ 2$ Keperawatan & 0 & 0 \\
\hline \multirow[t]{3}{*}{4} & Status Pernikahan & & \\
\hline & a. Menikah & 52 & 80.0 \\
\hline & b. Belum Menikah & 13 & 20.0 \\
\hline \multirow[t]{3}{*}{5} & Memiliki Anak & & \\
\hline & a. Sudah & 45 & 69.2 \\
\hline & b. Belum & 20 & 30.8 \\
\hline \multirow[t]{3}{*}{4} & Status Kepegawaian & & \\
\hline & a. PNS & 40 & 61.5 \\
\hline & b. BLUD & 35 & 38.5 \\
\hline \multirow[t]{4}{*}{5} & Ruangan Dinas & & \\
\hline & a. Instalasi Gawat Darurat (IGD) & 26 & 40.0 \\
\hline & b. Ruangan Isolasi Serunai & 27 & 41.5 \\
\hline & c. Ruangan Anak & 12 & 18.5 \\
\hline
\end{tabular}

\section{Kualitas Kehidupan Kerja Perawat}

Berdasarkan penelitian didapatkan bahwa dari 65 Total Responden Kualitas Kehidupan Kerja Perawat dalam Kategori Sedang Sebanyak 49 orang (75.4\%), diantaranya memiliki Work Life /Home Life berkategori sedang sebanyak 29 orang $(44.6 \%)$, sebagian besar memiliki Work Design berkategori sedang sebanyak 44 orang (67.7\%), sebagian besar memiliki Work Context berkategori sedang sebanyak 42 orang (64.6\%) dan sebagian besar memiliki Work World berkategori baik sebanyak 40 orang $(61.5 \%)$. Detail lebih lanjut dapat dilihat pada tabel di bawah:

Tabel 2. Kualitas Kehidupan Kerja Perawat

\begin{tabular}{clcccc}
\hline No & $\begin{array}{c}\text { Variabel dan Sub } \\
\text { Variabel }\end{array}$ & $\begin{array}{c}\text { Rendah } \\
(\%)\end{array}$ & $\begin{array}{c}\text { Sedang } \\
(\%)\end{array}$ & $\begin{array}{c}\text { Baik } \\
(\%)\end{array}$ & $\begin{array}{c}\text { Total } \\
(\%)\end{array}$ \\
\hline 1 & Kualitas Kehidupan & 9 & 49 & 7 & 65 \\
& Kerja Perawat & $(13.8)$ & $(75.4)$ & $(10.8)$ & $(100)$ \\
2 & Work Life/Home Life & 12 & 29 & 24 & 65 \\
& & $(18.5)$ & $(44.6)$ & $(36.9)$ & $(100)$. \\
3 & Work design & 0 & 44 & 21 & 65 \\
& & $(0.0)$ & $(67.7)$ & $(32.3)$ & $(100)$. \\
4 & Work Context & 9 & 42 & 14 & 65 \\
& & $(13.8)$ & $(64.6)$ & $(21.5)$ & $(100)$. \\
5 & Work World & 0 & 25 & 40 & 65 \\
& & $(0.0)$ & $(38.5)$ & $(61.5)$ & $(100)$. \\
\hline
\end{tabular}

\section{Kualitas Hidup}

Berdasarkan Penelitian didapatkan bahwa dari 65 responden memiliki kualitas hidup dalam kategori sedang sebanyak 42 orang (64.4\%). Detail lebih lanjut dapat dilihat pada tabel 3 di bawah:

Tabel 3. Kualitas Hidup

\begin{tabular}{llcccc}
\hline No & Variabel & $\begin{array}{c}\text { Rendah } \\
(\boldsymbol{\%})\end{array}$ & $\begin{array}{c}\text { Sedang } \\
(\boldsymbol{\%})\end{array}$ & $\begin{array}{c}\text { Baik } \\
(\boldsymbol{\%})\end{array}$ & $\begin{array}{c}\text { Total } \\
(\boldsymbol{\%})\end{array}$ \\
\hline 1 & Kualitas & 1 & 42 & 22 & 65 \\
& Hidup & $(1.5)$ & $(64.4)$ & $(33.8)$ & $(100)$. \\
\hline
\end{tabular}

\section{Analisis SEM PLS \\ Analisis Outer Model (measurement model)}

Sebelum dilakukan pengujian hipotesis perlu dilakukan pengujian kelayakan data dengan mengukur validitas dan reliabilitas variabel teramati.

a. Uji Validitas Konvergen

Pada uji ini dilakukan 2 kali pengujian dapat dilihat pada Gambar dibawah ini:

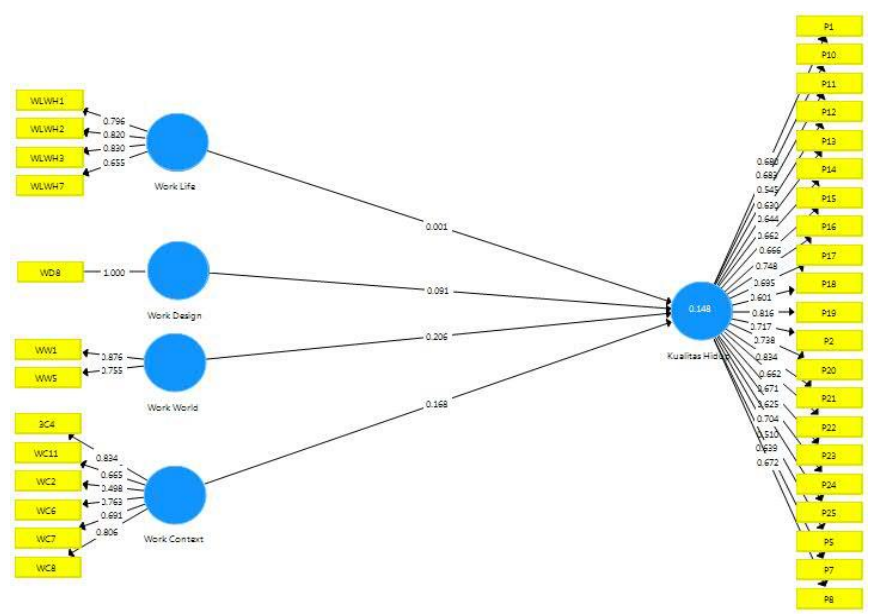

Gambar 1. Hasil Loading faktor Model Pengukuran (akhir)

Nilai muatan faktor (faktor loading) dipaparkan pada gambar 2 berada pada rentang nilai antara 0,510 sampai 1,000 artinya bahwa semua indikator mempunyai faktor loading lebih besar dari 0,5. Hasil ini menunjukkan bahwa semua indikator memiliki validitas konvergen yang baik. Dengan demikian, indikator telah dikatakan valid dalam mengukur masing-masing variabel latennya.

b. Uji Validitas Diskriminan

Uji validitas diskriminan dilakukan untuk mengetahui seberapa jauh perbedaan nilai validitas suatu variabel bila dibandingkan dengan variabel lainnya. Hasilnya terdapat pada tabel 4 dan 5 di bawah ini

Tabel 4. Nilai Average Variance Extracted AVE Construct Reliability and Validity

\begin{tabular}{ccccc}
\hline Matrix & Cronbach's Alpha & rho_A & Composite Reliability & Average Variance Extracted (AVE) \\
\hline Kualitas Hidup & 0.941 & 0.949 & 0.946 & 0.459 \\
Work Life/Work Work & 0.793 & 0.840 & 0.859 & 0.606 \\
Work Design & 1.000 & 1.000 & 1.000 & 1.000 \\
Work Contex & 0.826 & 0.926 & 0.862 & 0.516 \\
Work World & 0.513 & 0.544 & 0.801 & 0.669 \\
\hline
\end{tabular}


Febrian Rahmat Suwandi, Rahmi Fahmy, Dewi Murni, Nelwati, Mira Susanti dan Zifriyanti Minanda Putri, Analisis Hubungan Kualitas Kehidupan Kerja Perawat dengan Kualitas Hidup Dimasa Pandemi Covid-19 di Rumah Sakit Umum Daerah M. Natsir

Tabel 5. Nilai Fornell Larcker Criterion Discriminant Validity

\begin{tabular}{|c|c|c|c|c|c|}
\hline Fornell-Larcker Criterion & Kualitas Hidup & Work Context & Work Design & Work Life & Work World \\
\hline Kualitas Hidup & 0.677 & & & & \\
\hline Work Life/Work Home & 0.190 & 0.319 & 0.270 & 0.779 & \\
\hline Work Design & 0.279 & 0.589 & 1.000 & & \\
\hline Work Context & 0.324 & 0.718 & & & \\
\hline Work World & 0.329 & 0.493 & 0.432 & 0.539 & 0.818 \\
\hline
\end{tabular}

Tabel 4 menunjukkan bahwa nilai AVE dari keseluruhan variabel laten berkisar antara 0,516 sampai 1,000 artinya bahwa nilai AVE seluruh variabel lebih besar dari 0,5. Nilai akar kuadrat AVE seluruh variabel pada tabel 5 berkisar antara 0,677 sampai 1,000, artinya bahwa nilai akar kuadrat AVE seluruh variabel lebih besar dari 0,6. Hasil tersebut menunjukkan bahwa seluruh variabel laten yang digunakan dalam penelitian ini mempunyai validitas diskriminan yang baik.

\section{c. Reliabilitas Komposit}

Reliabilitas komposit merupakan reabilitas untuk mengukur variabel laten (Hair et al., 2010). Reliabilitas ini menggunakan koefisien reliabilitas untuk menjelaskan model pengukuran yang diuji dapat dilihat pada tabel 6 dibawah ini

Tabel 6. Nilai Reliabilitas Komposit

\begin{tabular}{ccccc}
\hline Matrix & Cronbach's Alpha & rho_A & Composite Reliability & Average Variance Extracted (AVE) \\
\hline Kualitas Hidup & 0.941 & 0.949 & 0.946 & $\mathbf{0 . 4 5 9}$ \\
Work Life/Work Work & 0.793 & 0.840 & 0.859 & 0.606 \\
Work Design & 1.000 & 1.000 & 1.000 & 1.000 \\
Work Contex & 0.826 & 0.926 & 0.862 & 0.516 \\
Work World & $\mathbf{0 . 5 1 3}$ & $\mathbf{0 . 5 4 4}$ & 0.801 & 0.669 \\
\hline
\end{tabular}

\section{Analisis Inner Model (structural model)}

Inner model merupakan model struktural untuk memprediksi hubungan kausalitas antar peubah laten. Evaluasi inner model adalah untuk mengevaluasi pengaruh konstruk antar laten dan pengujian hipotesis.

\section{R Square}

Tabel 7. R Square Masing-Masing Dimensi Penelitian

\begin{tabular}{ccc}
\hline Matrix & R Square & R Square Adjusted \\
\hline Work Life & 0.594 & 0.587 \\
Work Design & 0.520 & 0.513 \\
Wrok Contex & 0.686 & 0.681 \\
Work World & 0.550 & 0.543 \\
\hline
\end{tabular}

Tabel 8. R Square Variabel Penelitian

\begin{tabular}{ccc}
\hline Matrix & & \\
& R Square & R Square Adjusted \\
\hline Kualitas Hidup & 0.148 & 0.091 \\
\hline
\end{tabular}

Tabel 7 dan 8 menjelaskan nilai $\mathrm{R}$ square atau koefisien determinasi yang menunjukkan kemampuan masing-masing indikator dapat menjelaskan dimensi, dan kemampuan semua dimensi menjelaskan variabel laten.

1. Nilai $\mathrm{R}$ square sebesar 0,594 artinya indikator WLWH1, WLWH2, WLWH3,WLWH6 DAN WLWH7 dapat menjelaskan dimensi Work Life sebesar $59,4 \%$, sisanya $30,6 \%$ dijelaskan indikator lain.
2. Nilai $\mathrm{R}$ square sebesar 0,520 artinya indikator WD1, WD2, WD7 dan WD8 dapat menjelaskan dimensi Work Design sebesar 52\%, sisanya 48\% dijelaskan indikator lain.

3. Nilai R square sebesar 0,686 artinya indikator $\mathrm{WC} 2$, WC4, WC6, WC7, WC8, WC11 DAN WC17 dapat menjelaskan dimensi Work Context sebesar 68,6\%, sisanya $31,4 \%$ dijelaskan indikator lain.

4. Nilai R square sebesar 0,550 artinya indikator WW1 dan WW2 dapat menjelaskan dimensi work world sebesar 55\%, sisanya 45\% dijelaskan indikator lain.

5. Nilai $\mathrm{R}$ square sebesar 0,148 artinya dimensi Work Life, Work Design, Work Context dan Work World dapat menjelaskan kualitas hidup perawat sebesar $14,8 \%$, sisanya $85,2 \%$ dijelaskan indikator lain.

\section{Uji hipotesis model koefisien jalur}

Uji hipotesis ini merupakan analisis kausalitas yang dilakukan untuk mengetahui hubungan antar variabel. Analisis kausalitas dapat digunakan untuk mengetahui pengaruh yang terjadi antara variabel eksogen dengan variabel endogen. Variabel eksogen dinyatakan berpengaruh secara signifikan terhadap variabel endogen jika nilai $\mathrm{p}$ (probabilitas) $<0,05$. Hasil uji hipotesis hubungan kausalitas dipaparkan pada Tabel 9 sebagai berikut; 


\begin{tabular}{|c|c|c|c|c|c|}
\hline $\begin{array}{c}\text { Mean, Stidev, } \\
\text { T-Values,P- Values }\end{array}$ & $\begin{array}{l}\text { Original } \\
\text { Sampel } \\
\end{array}$ & $\begin{array}{c}\text { Sampel } \\
\text { Mean (M) }\end{array}$ & $\begin{array}{c}\text { Standard } \\
\text { Deviation (Std }\end{array}$ & $\begin{array}{l}\text { T-Statistik } \\
\text { (O/Stidev) }\end{array}$ & $\begin{array}{c}\text { P- } \\
\text { Values }\end{array}$ \\
\hline $\begin{array}{l}\text { WorkLife/HomeLife } \\
\text { Kualitas hidup }\end{array}$ & 0.001 & 0.008 & 0.115 & 0.007 & 0.497 \\
\hline $\begin{array}{l}\text { Work Degin } " \\
\text { Kualitas Hidup }\end{array}$ & 0.091 & 0.137 & 0.002 & 41.196 & 0.000 \\
\hline $\begin{array}{l}\text { Work Contex " } \\
\text { Kualitas Hidup }\end{array}$ & 0.168 & 0.226 & 0.039 & 4.307 & 0.025 \\
\hline $\begin{array}{l}\text { Work World " } \\
\text { Kualitas Hidup }\end{array}$ & 0.206 & 0.092 & 0.041 & 4.996 & 0.019 \\
\hline
\end{tabular}

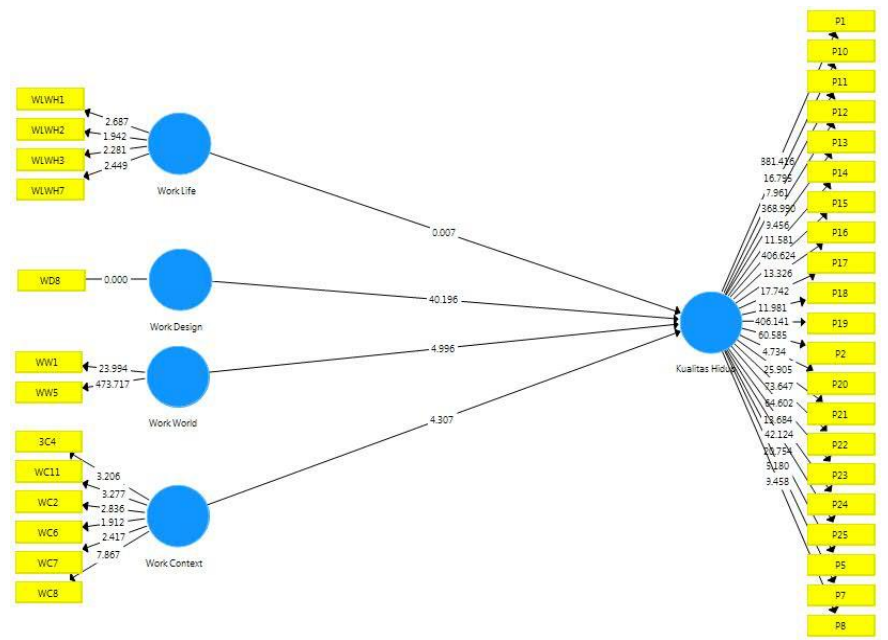

Gambar 2. Hasil path coefficient Model Struktural

H0: variabel dependen tidak berhubungan signifikan terhadap variabel independen

Ha: variabel dependen berhubungan signifikan terhadap variabel dependen

Dasar pengambilan keputusan dari uji hipotesis tersebut yaitu jika nilai probabilitasnya (nilai sig) $>0,05$ maka $\mathrm{H} 0$ diterima dan jika nilai probabilitasnya (nilai sig) $<0.05$ maka H0 ditolak. Hipotesis-hipotesis yang dapat diuraikan berdasarkan hasil yaitu:

1. Berdasarkan tabel 9 diperoleh nilai sample mean bernilai positif sebesar 0,001 dan nilai signifikansi sebesar 0,497>0,05, nilai T statistik sebesar 0,007 < $\mathrm{T}$ tabel 1,645 sehingga dengan demikian dapat disimpulkan bahwa dimensi work life / home life pada kualitas kehidupan kerja tidak berhubungan signifikan terhadap kualitas hidup perawat.

2. Berdasarkan tabel 9 diperoleh nilai sample mean bernilai positif sebesar 0,091 dan nilai signifikansi sebesar $0,000<0,05$, nilai $\mathrm{T}$ statistik sebesar 40,197 $>\mathrm{T}$ tabel 1,645 sehingga dengan demikian dapat disimpulkan bahwa dimensi work design pada kualitas kehidupan kerja berhubungan signifikan terhadap kualitas hidup perawat.

3. Berdasarkan tabel 9 diperoleh nilai sample mean bernilai positif sebesar 0,168 dan nilai signifikansi sebesar $0,025<0,05$, nilai $\mathrm{T}$ statistik sebesar 4,307 > $\mathrm{T}$ tabel 1,645 sehingga dengan demikian dapat disimpulkan bahwa dimensi work context pada kualitas kehidupan kerja berhubungan signifikan terhadap kualitas hidup perawat.

4. Berdasarkan tabel 9 diperoleh nilai sample mean bernilai positif sebesar 0,206 dan nilai signifikansi sebesar $0,019<0,05$, nilai $\mathrm{T}$ statistik sebesar 4,996 > $\mathrm{T}$ tabel 1,645 sehingga dengan demikian dapat disimpulkan bahwa dimensi work world pada kualitas kehidupan kerja berhubungan signifikan terhadap kualitas hidup perawat.

\section{Pembahasan}

\section{Hubungan Dimensi Work Life / Home Life pada Kualitas Kehidupan Kerja Dengan Kualitas Hidup}

Berdasarkan hasil didapatkan bahwa nilai sample mean bernilai positif sebesar 0,001 dan nilai signifikansi sebesar 0,497>0,05, nilai $\mathrm{T}$ statistik sebesar $0,007<\mathrm{T}$ tabel 1,645 sehingga dengan demikian dapat disimpulkan bahwa dimensi Work Life / Home Life pada kualitas kehidupan kerja tidak berhubungan signifikan terhadap kualitas hidup perawat. Dalam penelitian ini juga didapatkan dari 65 Responden 29 (44.6\%) diantaranya memiliki nilai dimensi Work Life / Home Life berkategori Cukup artinya pada dimensi ini kualitas kehidupan kerja perawat dalam menyeimbangkan antara pekerjaan ditempat kerja dan mampu bekerja lagi di rumah.

Menurut Brook and Anderson (2005) dalam penelitian (Oyoh et al., 2017) menjelaskan terkait dengan pengertian Work Life / Home life di mana dimensi ini merupakan hubungan pengalaman bekerja perawat dengan kehidupan di rumahnya. Dalam artian perawat dapat mencukupi atau memenuhi kebutuhan rumah tangganya, memperhatikan energi yang tersisa setelah bekerja, kesiapan akan perubahan jadwal ketika bekerja, dan kebijakan akan organisasi terhadap dirinya.

Hasil penelitian ini sejalan dengan definisi keseimbangan hidup yang menjelaskan bagaimana cara mengatur antara pekerjaan dan keluarga serta batasan antara keduanya untuk memperoleh keseimbangan, teori ini menjelaskan bukan tentang waktu yang mestinya sama namun secara luas menjelaskan keterlibatan peran agar hidup yang dijalani lebih bermakna dan selaras. Selain itu kehadiran peran seseorang terhadap keluarganya dapat meningkatkan psikologis yang baik dalam kehidupan (Romadlon, 2020).

\section{Hubungan Dimensi Work Design pada Kualitas Kehidupan Kerja Dengan Kualitas Hidup}

Berdasarkan hasil penelitian diperoleh nilai sample mean bernilai positif sebesar 0,091 dan nilai signifikansi sebesar $0,000<0,05$, nilai $\mathrm{T}$ statistik sebesar 40,197 > T tabel 1,645 sehingga dengan demikian dapat disimpulkan bahwa dimensi work design pada kualitas kehidupan kerja berhubungan signifikan terhadap kualitas hidup perawat.

Hasil Penelitian yang diperoleh pada dimensi Work Design dari 65 Responden 44 (67.7\%) sebagian besar responden berkategori Cukup artinya Kualitas 
seorang perawat dalam bekerja di mana adanya penilaian beban kerja, keterlibatan terhadap pekerjaan serta dapat mengambil keputusan akan tindakan yang dilakukan perawat dalam kategori cukup.

Perubahan yang terjadi pada masa Pandemi COVID-19 ini membuat pola kerja yang harus disesuaikan dengan protokol kesehatan, hal ini dapat menambah beban kerja perawat dan kondisi yang dialami oleh perawat menimbulkan keresahan terhadap dirinya sendiri karena adanya tanggung jawab yang lebih dari pada biasanya dan harus diselesaikan, hasil penelitian yang dilakukan oleh (Cahya et al., 2021) didapatkan beban kerja dan lingkungan kerja berpengaruh terhadap Kepuasan Kerja dibuktikan dengan nilai 0,193 atau $19,3 \%$ yang menunjukkan hubungan yang signifikan sedangkan $80,7 \%$ dari hasil penelitian ini dipengaruhi oleh variabel lain.

\section{Hubungan Dimensi Work Context pada Kualitas Kehidupan Kerja Dengan Kualitas Hidup}

Berdasarkan hasil penelitian diperoleh nilai sample mean bernilai positif sebesar 0,168 dan nilai signifikansi sebesar $0,025<0,05$, nilai $\mathrm{T}$ statistik sebesar 4,307 > T tabel 1,645 sehingga dengan demikian dapat disimpulkan bahwa dimensi work context pada kualitas kehidupan kerja berhubungan signifikan terhadap kualitas hidup perawat.

Hasil penelitian yang diperoleh pada dimensi Work Context dari 65 Responden 42 (67.7\%) sebagian besar berketegori Cukup artinya Kualitas seorang perawat berhubungan dengan manajemen, rekan kerja dan tim tenaga kesehatan lainnya dalam keterlibatan dan komunikasi yang baik dapat dilaksanakan berkategori cukup.

Berdasarkan penelitian yang dilakukan oleh (Muliantino, 2021) berkaitan dengan ketidaknyamanan yang ditimbulkan perawat di masa pandemi COVID-19, penelitian ini berkaitan dengan stres, depresi yang dialami oleh perawat digambarkan dengan gejala psikologis seperti, cemas yang berlebihan, perasaan kesal, sulit untuk melakukan relaksasi, kelelahan, kesulitan untuk beristirahat. Hasil penelitian ini menunjukkan dari 535 perawat yang bekerja di rumah sakit dan menjadi perawat pelaksana dalam penanganan pasien COVID-19 di 24 Provinsi di Indonesia mayoritas perawat mengalami respons stress dan depresi dalam skala normal namun 127 orang diantaranya $(23,7)$ dengan tingkat stress dan depresi skala sedang.

\section{Hubungan Dimensi Work World pada Kualitas Kehidupan Kerja Dengan Kualitas Hidup}

Berdasarkan penelitian diperoleh nilai sample mean bernilai positif sebesar 0,206 dan nilai signifikansi sebesar $0,019<0,05$, nilai $\mathrm{T}$ statistik sebesar 4,996 > T tabel 1,645 sehingga dengan demikian dapat disimpulkan bahwa dimensi work world pada kualitas kehidupan kerja berhubungan signifikan terhadap kualitas hidup perawat.

Hasil penelitian yang diperoleh pada dimensi Work World dan dari 65 Responden 40 (61.5\%) berkategori Baik artinya Kualitas seorang perawat terhadap hubungan sosialnya dengan masyarakat ataupun pasien dalam hal praktik keperawatan berkategori baik.

Gaji merupakan penghargaan atau imbalan yang diberikan kepada seseorang terhadap apa yang telah dilakukannya agar dapat meningkatkan semangat dalam bekerja dan dapat memperbaiki kinerja yang akan dicapai (Silalahi, 2020). Berdasarkan Keputusan Menteri Kesehatan Republik Indonesia Nomor HK.01.07/MENKES/278/2020 Tentang Pemberian Insentif dan Santunan Kematian terhadap Tenaga Kesehatan yang menangani pasien COVID-19 mengatakan bahwa bagi setiap tenaga kesehatan yang melakukan tindakan terhadap pasien COVID-19 akan diberikan insentif sesuai dengan profesinya. Risiko akan tingginya penularan virus COVID-19 pada tenaga kesehatan sewajarnya mereka diberi penghargaan atau imbalan yang cukup tinggi dengan demikian mereka juga dapat memenuhi kebutuhan sehari-hari untuk mereka konsumsi lebih dari biasanya.

\section{SIMPULAN}

Terdapat 3 dimensi pada kualitas kehidupan kerja perawat yang berhubungan signifikan dengan kualitas hidup di masa Pandemi COVID-19 di RSUD M. Natsir yaitu dimensi Work Design, Work Context dan Work World dengan nilai masing-masing dimensi 0,000, 0,025 dan 0,019 artinya (nilai sig) $<0,05$ sedangkan dimensi Work Life /Home Life (nilai sign) sebesar 0,497>0,05 dengan nilai $\mathrm{T}$ statistik sebesar $0,007<\mathrm{T}$ tabel 1,645 maka dimensi ini tidak berhubungan signifikan terhadap kualitas hidup perawat.

Banyak hal yang dapat ditingkatkan bagi pihak rumah sakit dan manajemen keperawatan terkait dengan beban kerja. Kondisi seperti ini menjadi tantangan bagi pihak manajemen keperawatan atau kepala ruangan agar lebih memperhatikan terkait jadwal yang akan diberikan kepada perawat, pengaturan akan tenaga kesehatan agar tidak terjadi peningkatan beban kerja dan penurunan akan kualitas hidup mereka terkait dengan fisik dan psikologis. Kemudian juga terkait dengan kepuasan kerja yang diperhatikan secara baik terhadap masingmasing perawat hal ini agar dapat meningkatkan produktifitas dan pelayanan keperawatan yang diberikan.

Peningkatan akan komunikasi yang baik antara sesama tenaga kesehatan, dan didukung melalui kelengkapan akan sarana dan prasarana yang memadai hal ini juga dapat menjadi perhatian lebih terutama Bagi Kepala Ruangan, Ketua Tim dan Perawat Pelaksana di dalam melakukan pelayanan keperawatan karena situasi pandemi COVID-19 banyak hal yang dapat 
memengaruhi hal tersebut, dengan peningkatan terhadap sarana dan prasarana diharapkan pelayanan yang diberikan berjalan dengan maksimal.

Hal terpenting juga dapat diperhatikan oleh pihak manajemen dengan situasi COVID-19 ini berhubungan dengan penghargaan yang diberikan berupa gaji yang mencukupi hal ini dapat memicu semangat dalam bekerja kemudian menimbulkan prestasi dan peningkatan atas kinerja yang dilakukan dan juga hal terpenting menumbuhkan semangat motivasi dalam bekerja. Pihak manajemen memperhatikan setiap dimensi yang peroleh dalam hasil penelitian ini akan berhubungan positif terhadap kualitas kehidupan perawat.

\section{DAFTAR PUSTAKA}

Astriani, Hamzah, W., \& Septiyanti. (2021). Hubungan quality of work life dengan kepuasan kerja pada pegawai honor di rsud h. Andi sulthan daeng radja kabupaten bulukumba. Window of Public Health Journal, $\quad 1(5), \quad 552-560$. https://doi.org/10.33096/woph.v1i5.230

Cahya, A., Astuti, R., \& Palupi, D. (2021). Analisis beban kerja dan lingkungan terhadap kepuasan kerja karyawan masa pandemi covid - 19. Jurnal Ilmu Manajemen, 10, 87-93.

Muliantino, M. R. (2021). Hubungan Stressor Dengan Ansietas, Stress Dan Depresi Perawat Terkait Pandemik COVID-19: Cross-Sectional Study. Jurnal Endurance: Kajian Ilmiah Problema Kesehatan, 6(2), 319-327.

Oyoh, O., Somantri, I., \& Yudianto, K. (2017). Kualitas kehidupan kerja perawat di puskesmas pangandaran. Padjadjaran Nursing Journal, 5(3), 289-296.

Remegio, W., Rivera, R. R., Griffin, M. Q., \& Fitzpatrick, J. J. (2021). The Professional Quality of Life and Work Engagement of Nurse Leaders. Nurse Leader, 19(1), 95-100. https://doi.org/10.1016/j.mnl.2020.08.001

Romadlon, F. (2020). Mendefinisikan ulang pola pembelajaran daring: antara sharing knowledge dan transfer etika. In COVID-19 Dalam Ragam Tinjauan Perspektif.

Silalahi, C. U. (2020). Manajemen SDM di masa pandemi Covid-19 di Industri Kesehatan ( Rumah Sakit ). 1-9.

Sugianto, Hariyati, \& Galleryzki. (2021). Pola shift perawat di masa pandemi covid-19. Journal of Telenursing (JOTING), Volume 3,(2020), 136144.

Viselita, F., Handiyani, H., \& Pujasari, H. (2019). Quality level of nursing work life and improvement interventions: Systematic review. Enfermeria Clinica, 29, 223-228. https://doi.org/10.1016/j.enfcli.2019.06.001 